\title{
Research on Higher Vocational College Student Innovation and Entrepreneurship Education System--Taking Business English of Hainan College of Economics and Business for Example
}

\author{
Li Liü, a, Shouguan Huang ${ }^{2, b}$, Zhuanfeng $\mathrm{Li}^{3, \mathrm{c}}$ \\ ${ }^{1,2,3}$ Hainan College of Economics and Business, Haikou, China \\ ahnllwqh@163.com, 'b1149496868@qq.com, '983719760@qq.com
}

Keywords: Innovation and Entrepreneurship; System; Business English Major

\begin{abstract}
Cultivating innovative and entrepreneurial talents should focus on education. This article elaborates the development of the innovation and entrepreneurship education training system of higher vocational college students from six aspects: perfecting the talent cultivation quality standard, improving the innovative and entrepreneurial education course system, consummating the innovative and entrepreneurial education practice teaching system, developing high-quality faculty and providing supporting conditions.
\end{abstract}

\section{Introduction}

Further reform in college innovation and entrepreneurship education is an urgent need for the state to implement innovation-driven development strategies, promote economic and efficiency upgrading, and an important measure to promote higher education comprehensive reform and higher-quality entrepreneurial employment of college graduates.

On May 4, 2010, the Ministry of Education issued Comments on Vigorously Promoting College Innovative and Entrepreneurial Education and Student Independent Entrepreneurship (Jiaoban[2010]No.3), requiring colleges to vigorously promote innovation and entrepreneurship education, developing entrepreneurship centers and all-round entrepreneurship support platforms, further implementing and improving supporting policies for student entrepreneurship, strengthening entrepreneurial guidance and service, forming collaborative efforts to promote college entrepreneurship education and student entrepreneurship. Subsequently, the state continuously introduced multiple documents, fully implementing college innovation and entrepreneurship education reform.

In recent years, colleges have experienced rapid development of innovation and entrepreneurship education, achieving fine results in revision and improvement of cultivation programs, development of innovative entrepreneurial education courses, innovation and entrepreneurship practice and innovation and entrepreneurship competitions, further improving innovation and entrepreneurship education system and reform.

\section{Development of the Cultivation System for Innovation and Entrepreneurship Education of Vocational College Students}

\subsection{Improving quality standard for talent cultivation}

\subsubsection{Implementing educational philosophy of moral education and talent cultivation}

In December 2016, General Secretary Xi Jinping emphasized at the national college ideological and political work conference, centering on moral education and talent cultivation, all-round and comprehensive ideological and political work in education, renovating higher education development, properly combining innovation and entrepreneurship education with ideological and political education. In terms of value leading, General Secretary Xi Jinping required completing of 
their studies and employment, and focusing on life value and historic mission, cultivating their sense of social responsibilities, striving for fulfilling the Chinese dream of great rejuvenation, making them establish the talent concept of "integration of morality and capacity, focusing on the former."

\subsubsection{Improving talent cultivation programs}

In 2016, Hainan College of Economics and Business (hereinafter referred to as "the College") introduced Revision for Talent Cultivation Programs and Management of Innovation and Entrepreneurship Credit Affirmation, integrating innovation and entrepreneurship education goals with professional training goals, encouraging students to have innovation and entrepreneurship practice at extracurricular time, and take various innovation and entrepreneurship competitions, appropriately converting their innovation and entrepreneurial practices and achievements into course credits, replacing credits of corresponding courses, implementing the flexible schooling system to relax their study length, allowing them to adjust academic progress, retaining academic status for innovation and entrepreneurship, providing institutional support to their innovation and entrepreneurship.

\subsection{Improving talent cultivation quality standards}

\subsubsection{Innovating classroom teaching mode}

Classroom teaching is the main channel for knowledge transference. Higher vocational colleges must focus on classroom teaching in innovation and entrepreneurship education, actively improving innovative and entrepreneurial teaching modes, making teaching flexible. It is proper for business English teaching to adopt group discussions, task-based learning, case-driven, case analysis, crazy spoken English and English corner, enhancing student interaction and sense of cooperation and teamwork, inspiring them to participate in innovation and entrepreneurship, vigorously improving their innovation and entrepreneurial thinking, ideas and capacities.

\subsubsection{Establishing innovative and entrepreneurial talent classes}

It is proper to take modern apprenticeship, introducing related cooperative enterprises to jointly establish special talent classes for professional cultivation, such as business English related "cross-border e-commerce class", "star-rated hotel business English class" and "Boao Forum reception service class", achieving close cooperation between the college and the enterprise, recommending students with innovative and entrepreneurial intention to take potential talent classes, jointly establishing potential talent cultivation classes with relevant enterprises, improving student entrepreneurial ability.

\subsubsection{Actively introducing SYB entrepreneurship courses}

SYB means "Start Your Business", a training program tailored by the United Nations International Labor Organization for entrepreneurs intending to start micro-enterprises. This college actively carried out campus "SYB entrepreneurship training" activities, accumulatively training more than 2,000 students free of charge, including more than 200 business English students, improving their employment concepts and independent employment awareness, and entrepreneurship knowledge and skills.

\subsubsection{Establishing typical characters for innovation and entrepreneurship}

Conducting one-year college student backbone training course youth innovation and entrepreneurship specialized training program, and students with the certificate of completion could be exempted from a second-year compulsory course, reserving talents for innovation and entrepreneurship competitions, actively launching “Campus Entrepreneurship Pioneer” selection, conducting entrepreneurship broadcast exhibition and voting through campus network and WeChat platform, selecting "typical” campus entrepreneurs, holding award presentation ceremonies and 
entrepreneurship sharing sessions, encouraging students to get engaged in innovation and entrepreneurship.

\subsection{Improving innovation and entrepreneurship education course system}

To improve pertinence and effectiveness of innovation and entrepreneurship education, this college has established the innovation and entrepreneurship course system of "innovation, entrepreneurship, general education, skills development, and entrepreneurship practice and incubation”, initially forming course characteristics.

\subsubsection{Establishing the hierarchical course system}

Offering different courses and different practical teaching activities against different grades

The first grade: Offering compulsory courses of Innovation and Entrepreneurship (MOOC), connecting with career development and employment guidance courses, requiring all freshmen and business English majors participating in the study.

The second grade: Integrating majors and conducting innovative thinking and entrepreneurial skills training, offering innovation and entrepreneurship courses in the form of publicly-selected courses, such as Entrepreneurial Management, Entrepreneurial Enterprise Strategy and Opportunity Selection, and Internet Entrepreneurship and Marketing Cases, offering elective courses such as Commercial Innovation Thinking and International Human Resource Management for business English majors.

The third grade: Arranging students to conduct innovation and entrepreneurship integrated practical training, such as VBSE(Virtual Business Social Environment) in cooperation with Seentao Technology Co., Ltd., actively recommending business English majors to take internships and employment in countries such as Singapore, Dubai and Maldives, broadening their international perspectives, laying down a sound foundation for overseas ventures.

\subsubsection{Organic combination of innovation and entrepreneurship education and professional education}

Innovation and entrepreneurship education focuses on student innovation and entrepreneurship awareness, innovative and entrepreneurial thinking, innovation and entrepreneurship skills, potentials and comprehensive abilities, without any conflict with professional education, but mutual promotion. The innovation and entrepreneurship course system should fully tap and enrich innovation and entrepreneurship education resources of professional courses, developing specialized courses improving entrepreneurial awareness, principles and ability. In terms of business English innovation and entrepreneurship education, it is proper to fully explore innovation and entrepreneurship education resources in professional courses such as international trade, business English, marketing, logistics management, and foreign-related accounting, making professional education and innovation and entrepreneurship education intersect, infiltrate, and integrate. In professional knowledge imparting, it is proper to strengthen innovation and entrepreneurship education, making students develop their entrepreneurial thinking and creative problem solving ability.

\subsubsection{Organic combination of online courses and offline courses}

According to the requirements of professional talent cultivation orientation and innovation and entrepreneurship education goals, 2 compulsory courses, Foundation for Student Entrepreneurship and Professional Development and Employment Guidance are offered, making students familiar with entrepreneurship basic knowledge and theory, basic processes and basic methods, laws and regulations and related policies, stimulating entrepreneurship awareness, improving social responsibility, innovation, and entrepreneurship. Relying on well-developed online communication platforms, innovation and entrepreneurship education MOOC, online courses and other network open courses are introduced, enriching innovation and entrepreneurship education course resources. This college has introduced College Student Innovation and Entrepreneurship Course (MOOC) on 
the "Wisdom Tree" online education platform. So far, 21 colleges in China have introduced this course, with 100,000 participants/times. This college has compiled the 2 textbook of Introduction to Innovation and Introduction to Entrepreneurship, in line with the actual situation of colleges in the province, introduced by 10 colleges in Hainan Province.

\subsubsection{Organic combination of theoretical courses and practical courses}

In addition to theoretical courses, it is necessary to conduct various practical teaching activities. Firstly, "Innovation and Entrepreneurship Education Month" activities are conducted regularly, and innovation and entrepreneurship series lectures, entrepreneurship competitions, innovation and entrepreneurship policy consultation, alumni entrepreneurship experience symposiums are arranged, improving innovation and entrepreneurship ability. Secondly, students are organized to participate in various college and national innovation and entrepreneurship competitions. In particular, students are organized to participate in China "Internet Plus" Student Innovation and Entrepreneurship Competitions. Thirdly, entrepreneurial associations, marketing associations, KAB clubs and other related associations are vigorously supported, conducting practice activities of associations, making them play promotion and education roles. Fourthly, "National College Student Innovation and Entrepreneurship Training Program" is organized and implemented by the Ministry of Education, actively inviting successful entrepreneurs, well-known investors, outstanding alumni, innovation and entrepreneurship competition guide experts to conduct innovation and entrepreneurship education seminars and guidance reports, improving the innovation and entrepreneurship guidance service system. Organic combination of theoretical teaching and practical teaching greatly improves effectiveness of innovation and entrepreneurship education.

\subsection{Improving the innovation and entrepreneurship education practice teaching system}

\subsubsection{Establishing campus sales practice platform}

This college has introduced the "www.nboto.com" college student micro-entrepreneurship project, establishing the "www.nboto.com" offline experiencing shop (with an area of approximately 160 square meters) in the first teaching building, the novel O2O "trust marketing" shopping platform developed with certain enterprises, providing college students with entrepreneurship platforms free from threshold, risk and cost. In response to Hainan free trade trial zone development, this college plans to upgrade the campus department store retail outlets to a cross-border e-commerce experiencing store, focusing on business English, international trade, and e-commerce students, providing them with convenient entrepreneurial platforms.

\subsubsection{Improving the college student entrepreneurial incubation center}

This college has established the campus college student entrepreneurial incubation center (with an area of approximately 360 square meters) with a total area of 690 square meters, hosting more than 30 teams. Currently, 18 business English entrepreneurial students plan to establish the human resource management company, providing short-term business English training to Hainan star-rated hotels, promoting cross-border internships and employment projects with this college, sending graduates abroad for internships and employment. This college constantly improves the quality of its incubation projects, planning to develop 8-10 innovative and entrepreneurial labs (with an area of approximately 500 square meters) in the integrated training building, expanding the scale of its incubation centers, operating in a diversified incubation model, merging the results of production, research and development, college student entrepreneurs, capital, markets, entrepreneurial supervisors and other resources into a single whole, providing one-stop innovation and entrepreneurship services.

\subsubsection{Actively participating in college student innovation and entrepreneurship competitions}

Every year, this college actively organizes and guides students to participate in various innovation and entrepreneurship competitions with outstanding results, such as the gold prize of 
"Qubei Online travel social service platform” project in the final of the 1st China "Internet Plus" College Student Innovation and Entrepreneurship Competition in the Hainan Competition Area and the bronze prize in the national finals. The bronze prize of business English entrepreneurial project "Hainan Waka Union Industry Co., Ltd." and excellence award of "Internet Plus Auto Parts Platform" project. And this college won "Excellent Organization Award" and "Collective Award", the only one of its kind in the competition group, ranking first in Hainan Province in terms of award quality and quantity. In addition, this college has actively organized students to participate in Hainan Province Entrepreneurial Competition, National Business English Practice Contest, "Challenge Cup - Rainbow Life" National Vocational College Innovation and Innovation and Entrepreneurship Contest, with fine results. Various competitions have enhanced student innovation and entrepreneurship awareness, confidence, and capacity.

\subsection{Developing high-quality faculty}

High-quality faculty is the key to college innovation and entrepreneurship education reform.

\subsubsection{Implementing faculty upgrading and transformation plan}

It is common that colleges are insufficient in full-time faculty members engaged in innovation and entrepreneurship education and multiple colleges rely on part-time faculty members of other related majors. To solve this problem, it is proper to implement upgrading and transformation programs for faculty members, actively carrying out special training for innovation and entrepreneurship education, guiding their transition from part-time to full-time innovation and entrepreneurship education, continuously improving their innovation and entrepreneurship education standards. Since 2015, this college has repeatedly organized KAB entrepreneurship faculty training courses, involving more than 40 employment specialists, counselors, and faculty members, cultivating a group of young and middle-aged entrepreneurship education faculty members with advanced teaching concepts and skills.

\subsubsection{Establishing the team of innovation and entrepreneurship education supervisors}

Implementing the innovation and entrepreneurship education supervisor system, actively introducing well-known entrepreneurs, venture capitalists and senior management talents with entrepreneurial background and actual experience to serve as innovation and entrepreneurship education supervisors, providing innovation and entrepreneurship guidance to students. At present, this college has 153 innovation and entrepreneurship education supervisors, and 10 business English education supervisors. The innovation and entrepreneurship education supervisor system can expand the innovation and entrepreneurship education faculty, solving the problem of shortage of full-time experienced faculty members, applying social resources to support and promote outstanding entrepreneurial projects.

\subsection{Providing Support and Guarantee Conditions}

\subsubsection{Establishing the special working mechanism}

This college has established a leading group for innovation and entrepreneurship education headed by the Party secretary, involving Party and administrative leaders, specific leaders, Office of Enrollment and Employment, secondary school, centering on the comprehensive and overall participation, guidance and promotion of "college, school and major" three-in-one employment and entrepreneurial work organization system.

\subsubsection{Establishing the innovation and entrepreneurship school}

To promote the development of innovation and entrepreneurship education, this college has taken lead in establishing the innovation and entrepreneurship school in Hainan Province, arranging the principal and special funds, offering special talent classes in conjunction with former professional schools, cultivating potential innovative and entrepreneurial talents, exploring 
innovation and entrepreneurship development, taking lead in innovation and entrepreneurship education in Hainan Province.

\subsubsection{Introducing guidance documents}

This college has successively introduced 2 documents: Implementation Program of Further Innovation and Entrepreneurship Education Reform of Hainan College of Economics and Business and Comments of Hainan College of Economics and Business on Further Strengthening and Improving College Student Employment and Entrepreneurship, providing guidance and institutional guarantee to standardization and specialization of innovation and entrepreneurship education.

\subsubsection{Improving the mechanism and system development}

This college has established the joint coordination mechanism, involving the Academic Affairs Department focusing on courses in combination with majors, the Youth League Committee and the Office of Recruitment and Employment focusing on practice and teaching, the School of Innovation and Entrepreneurship focusing on cultivation of potential talents, forming the joint coordination mechanism involving the Academic Affairs Department, the Office of Recruitment and Employment, the School of Innovation and Entrepreneurship, the Youth League Committee, Student Work Office and secondary schools.

\section{Conclusion}

To further reform college innovation and entrepreneurship education, it is necessary to thoroughly study the talent cultivation system, promptly improving education and teaching concepts, clarifying standards for talents with "both ability and political integrity," innovating talent cultivation models, enhancing major settings and course systems, improving teaching systems, developing high-quality combined full-time and part-time faculty, providing support and guarantee to innovation and entrepreneurship education. It is necessary to correctly handle the relationship between professional education and innovation and entrepreneurship education, integrating innovation and entrepreneurship education with local economic development, focusing on students, staged and layered cultivation, exploring various education models, developing diverse practical activities, vigorously inspiring student innovation and entrepreneurship, constantly improving innovation and entrepreneurship capacities, cultivating sufficient national and local innovative and entrepreneurial talents, making contributions to the innovative country in terms of education.

\section{Fund Project}

Research on Higher Vocational College Student Innovation and Entrepreneurship Education System - Taking Business English of Hainan College of Economics and Business for Example, Hainan Provincial Higher Education Teaching Reform Research Project Initiation Topic 2016 (Project No.: Hnjg2016-66)

\section{References}

[1] Wu Qinger, Model and Implementation Path of Business English Innovation and Entrepreneurship Education [J] Vocational Education for Mechanical Industry, 2017(10):31-33.

[2] Zhan Wenjing, Yu Yaojun, Development of the Higher Vocational College Business English Innovative and Entrepreneurial Talent Cultivation System against Cross-Border E-commerce [J] Journal of Kaifeng Institute of Education, 2017, 37(02):161-162

[3] Liu Tingting, Analysis of the Development of the Higher Vocational College Business English Course System Focusing on Innovation and Entrepreneurship [J] Science \& Technology 
Economy Market, 2016(05):256+255.

[4] Hao Jie, Wu Aihua, Hou Yongfeng, Development and Enlightenment of the US Innovation and Entrepreneurship Education System [J] Research on Higher Engineering Education, 2016(02):7-12.

[5] Yin Xiang, Xi Furong, Development of the College Student Innovative Talent Cultivation System [J] Chinese University Science \& Technology, 2015(03): 75-77.

[6] Ma Yongbin, Bai Zhe, Research and Exploration of College Innovation and Entrepreneurship Education [J]. Educational Research of Tsinghua University, 2015, 36(06): 99-103. 